\title{
The Impact of Trade Facilitation on Export Performance in Six ASEAN Countries Period
} 2005- 2016

Luh Putu Gita Santhi ${ }^{*}$

Ni Putu Wiwin Setyari ${ }^{2}$

\section{${ }^{1,2}$ Faculty of Economics and Business, Udayana University (Unud), Bali, Indonesia. \\ ${ }^{2}$ Email:santhigita27@gmail.com \\ Email:wiwin.setyari@unud.ac.id}

Licensed:

This work is licensed under a Creative Commons Attribution 4.0 License.

Keywords:

Trade facilitation

Export performance

ASEAN.

Accepted: 1 November 2019

Published: 20 November 2019

\begin{abstract}
Trade Facilitation (TF) is a form of simplifying the process of international trade activities. The purpose of this study was to investigate how TF impacts on export performance in six ASEAN countries. Port efficiency, burden customs procedure and fixedbroadband are used to construct indicators for measuring TF. This study used 72 samples with a saturated sampling method. Data collection techniques used are non-participants and analysis technique used is panel data regression. The show estimate that TF reform improves export performance in six ASEAN countries. It means an increasing efficiency of TF can improve export performance. Partially, port efficiency and fixed broadband have a significant positive effect on export performance. This means, port efficiency as measured by the quality of infrastructure and a large number of people used fixed broadband subscription can improve export performance. Then for the burden customs procedure variable shows a significant negative effect on export performance. This happened because of the emergence of complicated exporters' views on online export procedures, due to the lack of socialization by the government. The availability of a good $T F$ is the initial capital to dominate the international market and lead to an increase in exports.
\end{abstract}

Funding: This study received no specific financial support.

Competing Interests: The authors declare that they have no competing interests.

Acknowledgement: This research is part of the research of Mrs. Wiwin Setyari as a lecturer at the Faculty of Economics and Business, Udayana University. An honour for me can be part of this research.

\section{Introduction}

According to Tambunan (2000) international trade is trade between or across countries which includes export and import activities. The existence of international trade activities is inseparable from differences in natural characteristics and the ability of a country in producing a product. Therefore all countries will unwittingly have a dependence on other countries. So the economic activities of a country cannot be separated from the state of the foreign economy (Agus, Gusti, \& Wayan, 2016). International trade activities are the engine of economic growth, which has a large impact on human life from social, economic and cultural. The positive impact of international trade is also felt by countries in Asia and Africa, which are identified in third world countries. Countries in ASEAN region also feel the impact of international trade.

The Figure 1 shows the average economic growth in ASEAN countries in the period from 1990 to 2016. The graph illustrates the overall economic condition of ASEAN after the formation of the ASEAN community in 1967. The formation of the ASEAN community is proof that the Southeast Asian region has opened an investment market and free market or in other words already open economy. Despite fluctuations and declines in 1998 and 2008 due to the monetary and global crisis, the economic growth shown was the result of international trade activities. International trade activities that have taken much focus on government is export. Export is trading activities in which the sale of goods from within the country occurs in compliance with applicable regulations (Taufik, 2014). Exports become a big concern because it provides a great opportunity for increasing foreign exchange (Rejekiningsih \& Tri, 2012). The biggest impact of export activities making all countries in the world competes to expanding market share. The intense market expansion made the intensity and commodities offered more diverse. This causes intense competition in the 
international market. Besides intense competition in the form of product quality, technological sophistication and so on, international trade cannot be separated from a variety of barrier.

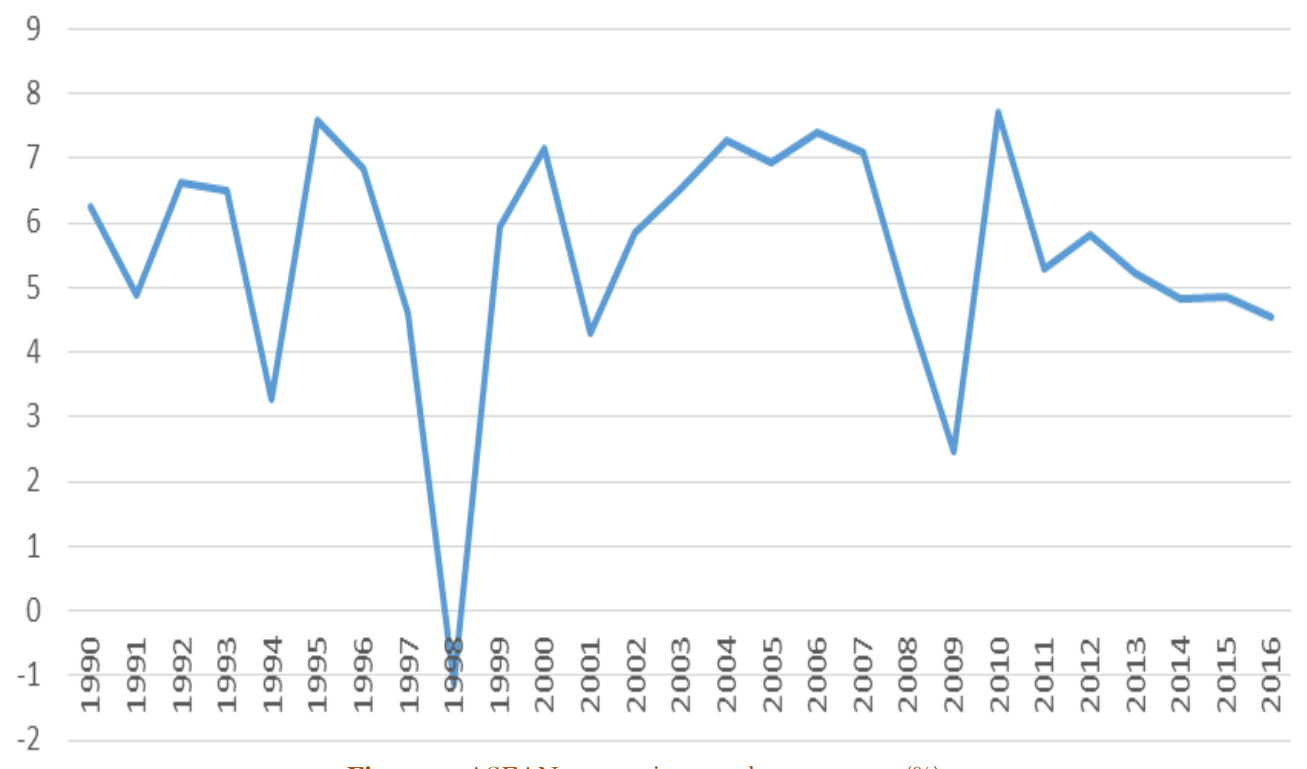

Source: World Bank (2018) (data processed).

Tariff barriers are obstacles in the form of imposing taxes on goods that cross national boundaries (Nopirin, 2015). Based on the World Trade Organization (WTO), non-tariff barriers are barriers to goods entering a country's borders in the form of government law from government authorities, regulations, policies, restrictions, provisions, and private sector business practices. Tariff and Non-tariff barriers (NTB) are the main instruments used to increase protection (Pangestu, Rahardja, \& Ing, 2015). Protection, in this case, is the protection of domestic industries from the scouring of imported goods.

According to the WTO, the application of a non-tariff barriers policy is permissible under certain circumstances but if excessive can cause concern for exporters. It is caused implementation of policy can affect $15-30 \%$ of the products traded. In addition, the existence of excessive non-tariff policies will have an impact on declining export performance. This decline in export performance has a negative impact on the economy at large. Efficiency is the main determinant for every country to compete in the global economy because it can encourage export competitiveness (Luthfianto, Priyarsono, \& Barreto, 2016). Increasing national competitiveness is influenced by various factors both from outside and from within the country. These factors are inflation, US dollar exchange rate and price (Suparsa \& Martini, 2016) FDI, interest rates, and IHPB Pramana and Meydianawathi (2013) and other factors. But there are endogenous factors in a country that have an important role in increasing competitiveness which leads to increased export performance. This factor is trade facilitation. Trade facilitation can minimize the negative impact of non-tariff barriers which of course can improve export performance.

Quoted from the WTO (2018) trade facilitation is a mechanism to simplify, modernize and harmonize the processes of exports and imports. More broadly, trade facilitation includes improving transportation infrastructure, eliminating government corruption, changes in non-tariff barriers, reduction in customs tariffs, export promotion, and marketing in exports (Grainger, 2008). At the international level, trade facilitation is an important aspect of world trade. WTO negotiations, GATT articles V, VIII, and X talk about trade facilitation which specifically addresses freedom of transit, costs, and formalities, as well as publication and administration of trade regulations. Big attention of international institution to trade facilitation due to trade facilitation has a positive impact on a country's exports and economic development of a country.

Based on Adb and Unescap (2013) trade facilitation has a positive impact in the long term, such as increasing national competitiveness, increasing the participation of small and medium enterprises (SMEs) in international trade, increasing the flow of Foreign Direct Investment (FDI), and of course boils down to increasing economic growth. Some of these positive impacts can certainly improve the economy on a macro scale and ultimately lead to poverty alleviation, which is in line with SDG's commitment. Trade facilitation has also been recognized as important policy options for economic growth and poverty alleviation in developing countries (Perera, Mahinda, \& Stuart, 2017). In this research trade facilitation measuring with three indicators, there are port efficiency, burden customs procedure, and fixed- broadband. Three indicators were chosen based on World Bank report and Logistic Performance Index report. For General, trade facilitation conditions in ASEAN are quite good compared to other developing countries. 


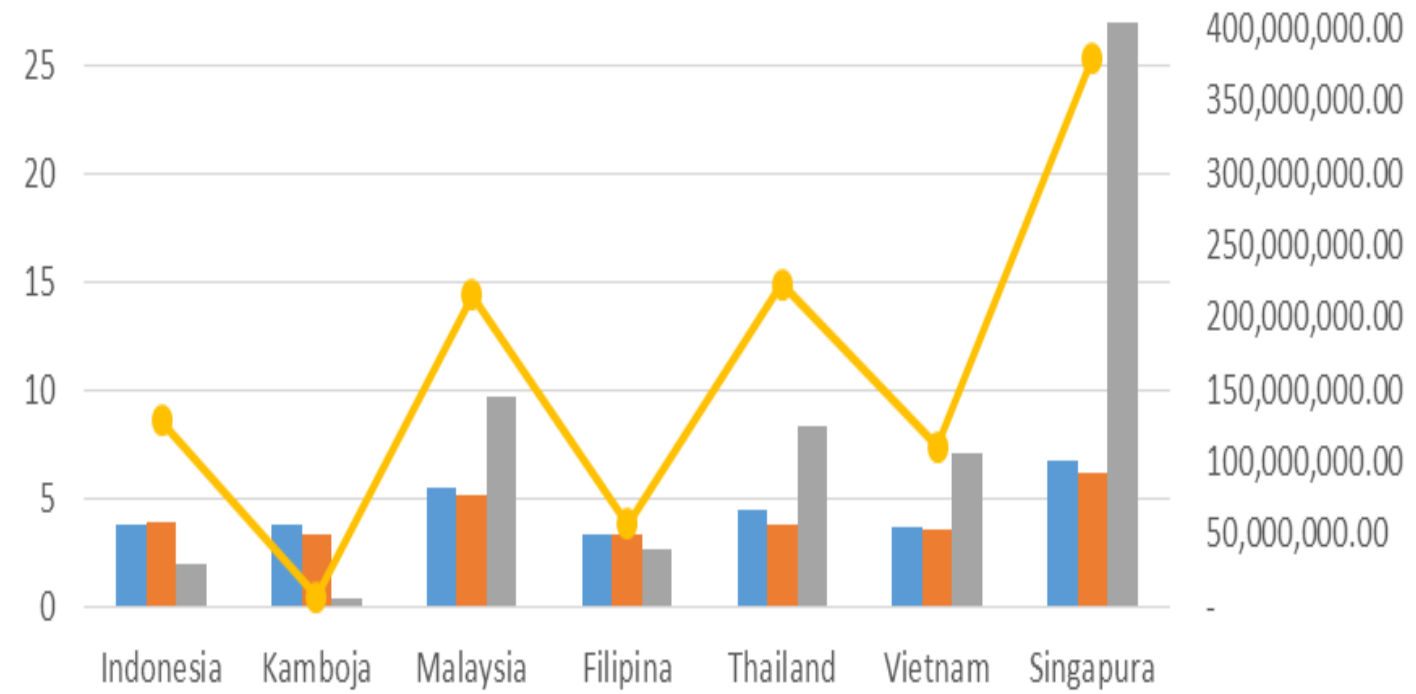

Port Efficiency Burden Customs Procedure $\backsim$ Fixed Broadband $\leadsto$-Export Value

Figure-2. Average trade facilitation conditions and ASEAN export performance 2012-2016. Source: World Bank and WITS (Data processed) (2019).

The Figure above shows the conditions of trade facilitation in ASEAN. As a whole, it seems that Singapore has a good export performance which is illustrated by the value of exports. The export performance is supported by a high trade facilitation index value, with a high percentage of fixed broadband usage. Whereas Cambodia shows a low export performance with a low quality of trade facilitation. Based on the Lpi (2016) Singapore State was ranked first in customs performance. Then according to the Wef (2016) Singapore is ranked second in the best port infrastructure and is supported by a high percentage of fixed broadband usage. Different from Singapore, Cambodia which is still ranked 77 for customs performance and 76 in the assessment of port infrastructure. While the rest, namely Malaysia, Thailand, Philippines, Indonesia, and Vietnam are still in the 30 s and below.

Quoted from beritasatu.com and CNN Indonesia, Indonesian ports have weaknesses in infrastructure and superstructure. Indonesian ports only have an average depth of 6-12 meters. This resulted in only small to medium vessels that could lean. This is different from the condition of neigh-boring country ports such as Singapore and Malaysia. Ports in Singapore and Malaysia have an average depth of up to 14.5 meters. This condition causes Indonesia to depend on the ports of Singapore and Malaysia as collecting ports (hub port). This dependence resulted in Indonesia's logistics costs being high and having a negative impact on export performance.

World Bank Group (2016) shows that the condition of Indonesia's port infrastructure is still far below that of neigh-boring countries, namely Singapore and Malaysia and even below Vietnam. As a result, there is a swelling of trade costs reflected in the percentage of logistics costs to GDP. Based on a statement from Darmin, the Indonesia Coordinating Minister for Economic Affairs, the average percentage of Indonesia's logistics costs reached $24 \%$ of GDP. While the average logistics costs of other countries are almost half, which is $15 \%$ of GDP. If this is not addressed, it will cause a decline in national competitiveness and result in lower export performance. Therefore, improvements to the aspects of trade facilitation in supporting export activities need to be considered and given special attention from the government. The object in this study only uses six ASEAN Member Countries. This is due to the lack of data needed from 3 countries, namely, Myanmar, Laos and Brunei Darussalam. This research also does not include the Singapore State, because based on Logistic Performance Index report Singapore is in 10 countries that have the best quality trade facilitation in the world. That's why Singapore not to be included as an object of research because it cannot represent a general condition of trade facilitation in ASEAN. Based on the background of the problem described, the objectives of this study are:

1) Explain the partial influence of port efficiency variables, burden customs procedures and fixed broadband variables on export performance in the period of 2005-2016 in six ASEAN countries.

2) Explain the simultaneous effect of port efficiency variables, burden customs procedure and fixed broadband on export performance in the period of 2005-2016 in six ASEAN countries. 


\section{Literature Review}

In this era of globalization, international trade activities are not only fulfilling needs. The purpose of international trade has changed from time to time. Initially only to make ends need, it changed into a sign of the strength of a country through world economic control and hoarding wealth in the form of foreign exchange. Therefore, each country competes in competing in the international market. Various ways are taken in market control. Starting from production technology, trade politics, cooperation and joining communities with other countries, to enforce tariff and non-tariff policies. On the porter diamond theory, there are endogenous factors that play an important role in creating a national competitive advantage. These factors are the role of government and opportunity. The role in question is not as a player in the industry, but with the authority possessed to provide facilities, catalysts, and challenges for the industry. The government advocates and encourages the industry to reach a certain level of competitiveness. These things can be done by the government through incentive policies, in addition to policies regarding the ease of holding exports can also support national competitiveness, especially in the international market. The role of the government described by Porter above is one of the keys to increasing national competitiveness.

In practice, trade facilitation has a close relationship with the economy. It causes the trade facilitation greatly affects the costs of the trading process. In economic theory especially economics institutions, costs that arise outside of production costs and certainly not desirable for economic actors are often called transaction costs. Based on Yustika (2012) defined transaction costs as costs for negotiating, measuring, and forcing an exchange. Then according Yustika (2012) transaction costs are interpreted to include three broader categories, including information seeking, negotiation costs and decisions or executing contracts, and monitoring costs, coercion, and compliance. The high transaction costs in trade and inefficiencies in the process of implementation can be reduced through reform and construction of trade facilitation in a country Luthfianto et al. (2016). The reform and construction of the trade facilitation in question is the improvement of bureaucracy in customs and ports and infrastructure improvements to support export activities. According to the WTO, trade facilitation is a simplification and harmonization of international trade procedures, including, practice activities and formalities involved in the collection, presentation, communication and processing of data and other information needed for the movement of goods in international trade. Trade facilitation has the aim of harmonizing certain rules between countries to achieve efficiency, transparency and predictability based on internationally accepted norms, standards and practices (Porto, 2015). Other research by Orliac, Moise, and Minor (2011) define trade facilitation as a policy and steps that aim to reduce trade costs to increase efficiency in the international trade chain. More broadly, trade facilitation interpreted by UNCTAD or APEC includes customs, transportation and transit, banking and insurance, business and telecommunications practices.

Research conducted by Busse, Hoekstra, and Koniger (2012) entitled The Impact of Aid for Trade Facilitation on the Costs of Trading, where using the panel data method found that trade facilitation has an important role in reducing trade fees. Statistically, trade facilitation has a significant effect on trade costs. An empirical study in 77 countries by Yadav (2014) used the gravity model found that trade facilitation (measured by physical infrastructure, ICT, business environment, and border efficiency) generally had a positive impact on the trade flow (export or import). Each study uses different export performance measures. Research on post-crisis export performance in Indonesia uses three benchmarks at once, namely, export growth, export value, and export volume (Athukorala, 2006). Then two studies that discuss the export performance in Asia and the effects of trade facilitation on sectoral trade use export values as a benchmark (dependent variable) (Redding \& Venables, 2004); (Martínez-Zarzoso \& Laura, 2007). Based on the research, this study used the value of export to measuring export performance. There are three indicators used for measuring trade facilitation in this research. The indicator are port efficiency, burden customs procedure, and fixed- broadband. Port efficiency and burden customs procedure be selected to indicators refers to Logistic Performance Index publications as a survey institution to measures the convenience of a country in doing business. In addition, these two indicators become the biggest barriers in export activities, because almost half of the export process takes in port and customs (pre, customs, and post-clearance).

Port efficiency in this research measured by the quality of infrastructure. World Bank publications regarding the quality of port infrastructure in the form of the index were used in this study. The index range used from 1-7 the results of the indicator assessment. Indicators used in assessing the quality of infrastructure in accordance with the type of port. The following are explained in Table 1. 
Table-1. Port classification for assessment infrastructure quality.

\begin{tabular}{|c|c|}
\hline Type of port & Port classification \\
\hline Primer & $\begin{array}{l}\text { 1) Distance from } 500 \text { to } 1,000 \text { miles with other } \\
\text { international hub ports; } \\
\text { 2) The depth in front of the dock is a minimum of - } \\
12 \text { M LWS; } \\
\text { 3) Has a container length of at least } 350 \mathrm{~m} \text {; } \\
4 \text { Has } 4 \text { crane; } \\
\text { 5) The minimum container yard is } 15 \mathrm{ha} \text {; } \\
6) \quad \text { The minimum volume of loading and unloading } \\
\text { activities is } 2,500,000 \text { TEUs / year. }\end{array}$ \\
\hline Secondary & $\begin{array}{l}\text { 1) Distance from } 200 \text { to } 500 \text { miles with other } \\
\text { international hub ports; } \\
\text { 2) The depth in front of the dock is a minimum of }-9 \\
\text { M LWS; } \\
\text { 3) Has a container length of at least } 250 \mathrm{~m} \\
4) \quad \text { Has } 2 \text { crane } \\
\text { 5) The minimum container yard is } 10 \text { ha } \\
6) \quad \text { The volume of loading and unloading activities is } \\
\text { at least } 1,500,000 \text { TEUs / year. }\end{array}$ \\
\hline $\begin{array}{l}\text { Collection } \\
\text { Port }\end{array}$ & $\begin{array}{l}\text { 1) Has a distance of } 50-100 \text { miles with other } \\
\text { national ports; } \\
\text { 2) Has technical port conditions with depth in front } \\
\text { of the pier } \\
\text { minimum }-9 \text { M LWS; } \\
\text { 3) has a multipurpose pier length of at least } 150 \mathrm{Om} \text {; } \\
\text { 4) minimum of } 50 \text { tons of mobile crane facilities; } \\
\text { 5) Being close to the area of national economic } \\
\text { growth. }\end{array}$ \\
\hline $\begin{array}{l}\text { Feeder } \\
\text { Port }\end{array}$ & $\begin{array}{l}\text { 1) Has a technical condition of the port with } \\
\text { minimal depth in front of the pier }-4 \mathrm{M} \mathrm{LWS} \\
\text { 2) } \quad \text { Has a dock length of at least } 70 \mathrm{~m} \text {. }\end{array}$ \\
\hline $\begin{array}{l}\text { National/ } \\
\text { Internatio } \\
\text { nal Special } \\
\text { port }\end{array}$ & $\begin{array}{l}\text { The weight of the ship is } 3000 \text { DWT or more; } \\
\text { Dock length } 70 \mathrm{M} \text { or more; } \\
\text { Depth in front of the pier }-5 \mathrm{M} \text { LWS or more. }\end{array}$ \\
\hline $\begin{array}{l}\text { f. } \quad \text { Regional } \\
\text { Special Port }\end{array}$ & $\begin{array}{l}\text { 1) The weight of the ship is } 1000 \text { DWT and less } \\
\text { than } 3000 \text { DWT; } \\
\text { 2) The pier length is less than } 70 \text { M concrete / steel } \\
\text { construction; } \\
\text { 3) Depth in front of the dock is less than }-5 \text { M LWS. }\end{array}$ \\
\hline $\begin{array}{l}\text { g. Local } \\
\text { Special Port }\end{array}$ & $\begin{array}{l}\text { T) The weight of the ship is less than } 1000 \text { DWT; } \\
\text { 2) The dock length is less than } 50 \mathrm{M} \text { with wood } \\
\text { construction; } \\
\text { 3) } \quad \text { Depth in front of the brake dock from -4 M LWS. }\end{array}$ \\
\hline
\end{tabular}

The indicator above will be converted on a 1-7 scale using the following formula:

$$
6 x\left(\frac{\text { country value-sample minimum value }}{\text { sample maximum value-sample minimum value }}\right)+1
$$

Good quality of port infrastructure will provide efficiency in the export process. This efficiency can further reduce shipping costs and can increase trading volume (Dick, 2008). In addition, it allows the handling of larger trading volumes and increases the diversification of traded goods. According to Wilson, Mann, and Tsunehiro (2003) shows that improvements in port efficiency have a positive and significant effect on trade and are followed by improvements customs and implementation of e-commerce in the port and airport business environment. Empirical studies in South Africa also show that port efficiency has a positive effect on exports (Jordaan, 2014). Export performance has also support by customs performance. Customs performance in this research measuring by burden customs procedure. Burden customs procedures show the level of ease of care import-export licensing. Assessment and the range value of burden customs procedure same with port efficiency. Research conducted by Shujie and Zhao (2009) about the impact of customs modernization on competitive Chinese exports found customs efficiency has a significant impact in reducing trade-related costs 
and business performance management. The more efficient customs performance will have an impact on export-import activities in the country concerned. Various developing countries have proven that improvements and modernization in the customs sector have a positive impact on the economy. One example is in India in Milner (2008) study, where in 1999 there was modernization in the customs program. In 2000 India's customs revenues rose $14 \%$ year-on-year and the time for permits was reduced to 1-3 import days and 3-8 hours for exports. In addition, Wilson, Catherine, and Tsunehiro (2005) 's study on custom environments has a good impact on trade flows in various economic regions. Based on World Bank and Logistic Performance Index, the indicator of the burden customs procedure are the number of documents submitted to border protection authorities, the number of signatures required, the time needed in preparation of documents, and costs incurred in preparation of documents. With the same formula as port efficiency then an index value will be obtained with a range of values 1-7.

Besides these two indicators, fixed- broadband also supports export performance. The digital era, internet is the backbone of the economy because all business activities and international trade such as from looking for consumers, how to market products, payment methods, ways to enter the market, and so on require stable internet speed. Technology who provides high speed and stable internet service is fixed- broadband. According to Minges (2015) research, fixed broadband has download speeds up to $1000 \mathrm{MB} / \mathrm{s}$. Therefore the development of fixed broadband is very important to supporting export activities. According to Maryanti and Wirianto (2015) internet (fixed broadband) is not just an infrastructure but also a technology that fundamentally restructures the economic sector that encourages research and development, innovation and other important factors that contribute to the sustainability of economic growth.

This has been tested in various empirical studies. This was found in the thesis research conducted by Rosell (2015) which was based on The Internet and Trade, where the number of internet users had a significant positive impact on bilateral trade performance. In this research also stated that the greater the proportion of the population of a country accessing the internet has the potential to improve a wealth through increased trade. Clarke and Wallsten (2006) found that higher internet penetration rates in developing economies tended to increase export performance from developing economies to advanced economies. The study of Qiang, Carlo, and Kaoru (2009) in 2007, 99\% of households in Korea have enjoyed high-speed internet access, of which $90 \%$ subscribe to fixed broadband services. This has an impact on all industries in Korea, from the automotive, banking industry and other industries that have led to an increase in the Korean economy and Korea's global competitiveness in the international market.

\section{Methods}

The design in this study uses an associative quantitative approach. This research was conducted in six ASEAN countries, namely, Thailand, Indonesia, Malaysia, Cambodia, Vietnam, and the Philippines. There are four countries not included as research objects namely, Brunei Darussalam, Laos, and Myanmar. It causes no data in accordance with what researchers need. While the rest is Singapore, there is a reason why Singapore doesn't include as a research object. The reason is the condition of trade facilitation in Singapore better then ASEAN, so it cannot reflect trade facilitation condition in ASEAN. In this study, the data sources used are secondary data. These data were obtained from the official World Economic Forum (WEF) website, the World Integrated Trade Solution (WITS), the International Telecommunication Union (ITU), and the World Bank. In this study using a panel data regression model. Panel data regression is a regression that combines time series data with cross-section data (Widarjono, 2013). Processing data in this study uses program Eviews 9. In addition, panel data usage also does not require classical assumption tests. According to Damodar, Gujarati, and Dawn (2012) in the use of panel data the case of the occurrence of collinearity between variables is so small that the possibility of multicollinearity is also very low.

According to Widarjono (2013) there are three methods used in estimating panel data regression models are Common Effect, Fixed Effect, and Random Effect. The estimation of Common Effect regression is done by combining time series data with cross sections without looking at differences between time and individuals. Common Effect regression uses the Ordinary Least Square (OLS) method or the least squares technique to estimate panel data. In this estimation, data between countries is assumed to be the same in various time periods.

The second estimate, Fixed Effect, is a model that has intercept differences between countries but the intercepts are the same across time. Intercept differences can occur due to cultural differences, policies, etc. But slop between countries is the same. The Fixed Effect model uses a dummy variable to explain the difference in intercepts. This model is often called the Least Squares Dummy Variables (LSDV) technique. The last estimate is Random Effect. In this model, the disturbance variables may be interconnected between time and between individuals. In this model, the intercept differences are accommodated by the error terms of each country. The advantage of using this model is to eliminate heteroscedasticity. This model is often called the Generalized Least Square (GLS) technique.

Based on the explanation above, a structural equation can be made as follows:

$$
Y_{i t}=\alpha+\beta_{1} X_{1 i t}+\beta_{2} X_{2 i t}+\beta_{3} X_{3 i t}+e_{i t}
$$


Where denotes the countries in ASEAN, $t$ denotes a year ( $\mathrm{t} 2005, \ldots, 2016)$ and the variables are defined as follows:

- Yit or export performance is export performance is a reflection the results of exports of goods / services of six ASEAN countries for the period 2005-2016 to the world. The measurement of export performance is the value of exports using US $\$$ unit.

- X1it or port efficiency is a measure of the perception of business people on port facilities in six ASEAN countries for the period of 2005-2016. In this study the benchmark of port efficiency is the port infrastructure quality index value. The value range of the quality of port infrastructure is from one (extremely underdeveloped port infrastructure conditions) and seven (port infrastructure conditions are efficient in accordance with international standards).

- X2it or burden customs procedure is shows the level of ease of managing export-import licenses carried out by measuring business perceptions of customs procedural efficiency in six ASEAN countries. This measure uses index values from 2005-2016 in six ASEAN countries, and the range of values from one (extremely inefficient) and seven (extremely efficient).

- X3it or fixed broadband is a percentage of users per 100 residents who subscribe to high-speed internet access to the public in six ASEAN countries for the period of 2005-2016. Measurement of fixed broadband internet includes residents who subscribe for residential and organizational purposes.

- $\quad \beta(1 \ldots 3)$ is regression coefficient of each independent variable.

- $\quad$ eit is error. follows:

In this study there are three statistical tests used to determining the most appropriate model to choose, as

1) Chow Test

The Chow test is a statistical test that aims to determine whether the right model is used to estimate panel data. In this test, there are two models to be tested, namely the common effect and fixed effects models. The hypothesis used in this test is as follows:

\section{Ho: Common Effect model; H1: Fixed Effect model}

If the Chi-Square probability is more than 0.05 then the chosen model is the Common Effect and vice versa. When the chosen model is Fixed Effect, it is necessary to do the Hausman Test. This test aims to find out which model is right to use, whether Fixed Effect or Random Effect.

2) Hausman Test

The Hausman test is a statistical test used in selecting a model whether using a random effect model or a fixed effect model. The hypothesis used in this test is:

Ho: random effect model; H1: fixed effect model

If the Hausman test value is greater than Chi Square, then Ho is rejected, meaning that the chosen model is the fixed effect model and vice versa.

3) Lagrange Multiplier Test (LM Test)

Lagrange Multiplier (LM) test is a test to find out which estimation model is right used between random effects or common effects. This LM test was developed by Breusch Pagan. The LM test is based on the residual value of the common effect method. Here's the hypothesis:

Ho: common effect model; H1: random effect model

Because using the Breusch Pagan method, when determining the model estimation the reference is in the Pagan Breusch column. If the significance value shows a value of less than 0,05 then Ho is rejected. This means that the right estimation model is random effects, and vice versa.

Furthermore, after determining the estimation used, the $\mathrm{F}$ test is carried out. The $\mathrm{F}$ test is carried out to find out the relationship between the dependent and independent variables simultaneously. The test criteria used in the $\mathrm{F}$ test is to compare $\mathrm{F}$-count with $\mathrm{F}_{\text {-table. If }} \mathrm{F}_{\text {-count }}>\mathrm{F}$-table then $\mathrm{Ho}$ is rejected, meaning that the independent variable influences simultaneously on the dependent variable. If $\mathrm{F}_{\text {-count }}<\mathrm{F}_{\text {-table }}$ then $\mathrm{Ho}$ is accepted, meaning that the independent variable does not have a simultaneous effect on the dependent variable with a significance level of $5 \%$.

Then, to find out the relationship partially between the independent and dependent variables, then the ttest is performed on each variable. The test uses a real level of $5 \%$ with a degree of freedom $(\mathrm{df})=(\mathrm{n}-\mathrm{k})$. The test criteria is to compare the calculated values with $\mathrm{t}$-table and $\mathrm{t}$-count. If $\mathrm{t}$ - count $>\mathrm{t}$-table or $-\mathrm{t}$ - -ount $<-\mathrm{t}$-table then Ho is rejected, meaning that each independent variable tested has a significant positive effect on the dependent variable. If $\mathrm{t}-$ count $<\mathrm{t}-$ table or $-\mathrm{t}-$ count $>-\mathrm{t}$ - table then Ho is accepted, meaning that each independent variable tested does not have a significant negative effect on the dependent variable.

\section{Results and Discussion}

Panel data regression analysis is an analysis used to determine the magnitude of the influence of variables namely Port Efficiency (X1), Burden Customs Procedure (X2) and Fixed Broadband (X3) on Export Performance (Y). Before conducting panel data regression, the Chow-Test, Hausman-Test, and Lagrange 
Multiplier Test are needed in determining the estimation model used. Table 2 shows the results of the ChowTest test with the help of E-Views 9.0.

Table-2. Chow- test.

\begin{tabular}{|c|c|c|c|}
\hline \multicolumn{4}{|c|}{$\begin{array}{l}\text { Redundant Fixed Effects Tests } \\
\text { Equation: Untitled } \\
\text { Test cross-section fixed effects }\end{array}$} \\
\hline Effects test & Statistic & d.f. & Prob. \\
\hline Cross-section $\mathrm{F}$ & 265.407045 & $(5.63)$ & 0.0000 \\
\hline Cross-section Chi-square & 222.764374 & 5 & 0.0000 \\
\hline
\end{tabular}

The Chow-Test test results show the Chi-Square probability is less than 0,05, so the chosen model is a fixed effect as a panel data estimation model. After the Chow-Test produces a decision using the fixed effect method, then it is continued to determine the estimation of the model. The second stage in determining the estimation of this model is to see which estimation is right to use, whether a fixed effect or random effect through Hausman-Test. The following are the Hausman-Test results.

Table-3. Hausman- test.

Correlated Random Effects - Hausman Test

Equation: Untitled

Test cross-section random effects

\begin{tabular}{l|c|c|c}
\hline Test summary & Chi-Sq. Statistic & Chi-Sq. d.f. & Prob. \\
\hline Cross-section random & 4.783315 & 3 & 0.1884 \\
\hline
\end{tabular}

Based on the results of the Hausman-Test which shows a probability of more than 0,05, the estimated model used is a random effect. However, when random effects are selected, it is necessary to Lagrange Multiplier Test. This test is done to determine the estimated model between Common Effect or Random Effect. The following results are shown in Table 4.

Table-4. Lagrange multiplier test.

\begin{tabular}{|c|c|c|c|}
\hline \multicolumn{4}{|c|}{$\begin{array}{l}\text { Lagrange Multiplier Tests for Random Effects } \\
\text { Null hypotheses: No effects } \\
\text { Alternative hypotheses: Two-sided (Breusch-Pagan) and one-sided } \\
\text { (all others) alternatives }\end{array}$} \\
\hline & \multicolumn{3}{|c|}{ Test hypothesis } \\
\hline Test method & Cross-section & Time & Both \\
\hline \multirow[t]{2}{*}{ Breusch-Pagan } & 163.4586 & 3.341155 & 166.7997 \\
\hline & $(0.0000)$ & -0.0676 & $(0.0000)$ \\
\hline \multirow[t]{2}{*}{ Honda } & 12.78509 & -1.82788 & 7.747917 \\
\hline & $(0.0000)$ & -- & $(0.0000)$ \\
\hline \multirow[t]{2}{*}{ King-Wu } & 12.78509 & -1.82788 & 9.579020 \\
\hline & $(0.0000)$ & -- & $(0.0000)$ \\
\hline \multirow[t]{2}{*}{ Standardized Honda } & 19.36399 & -1.70985 & 6.408395 \\
\hline & $(0.0000)$ & -- & $(0.0000)$ \\
\hline \multirow[t]{2}{*}{ Standardized King-Wu } & 19.36399 & -1.70985 & 9.558413 \\
\hline & $(0.0000)$ & -- & $(0.0000)$ \\
\hline \multirow[t]{2}{*}{ Gourierioux, et al.* } & -- & -- & 163.4586 \\
\hline & & & $(<0.01)$ \\
\hline \multicolumn{4}{|c|}{ *Mixed chi-square asymptotic critical values: } \\
\hline $1 \%$ & 7.289 & & \\
\hline $5 \%$ & 4.321 & & \\
\hline $10 \%$ & 2.952 & & \\
\hline
\end{tabular}

Based on Table 4 using the Breusch-Pagan test method which has a probability value of less than 0.05, the exact estimation model used in this study is a random effect. After the selected estimation model is a random effect, then it is followed by the F- test and t- test with the help of E- Views 9.0. The F test and t- test are conducted to see how much influence each independent variable has on the dependent variable. 
Table-5. Panel data regression.

Dependent Variable: LOG(Export_perfomance)

Method: Panel EGLS (Cross-section random effects)

Periods included: 12

Cross-sections included: 6

Total panel (balanced) observations: 72

Swamy and Arora estimator of component variances

\begin{tabular}{|c|c|c|c|c|}
\hline Variable & Coefficient & Std. error & t-Statistic & Prob. \\
\hline $\mathrm{C}$ & 1.979207 & 0.514420 & 3.847450 & 0.0003 \\
\hline Port_Efficiency & 0.528667 & 0.115158 & 4.590782 & 0.0000 \\
\hline Customs_Procedure & -0.024268 & 0.123376 & -0.196697 & 0.8447 \\
\hline \multirow[t]{3}{*}{ Fixed_Broadband } & 0.078419 & 0.010690 & 7.335937 & 0.0000 \\
\hline & \multicolumn{2}{|c|}{ Effects Specification } & & \\
\hline & & & S.D. & Rho \\
\hline \multicolumn{3}{|l|}{ Cross-section random } & 0.979936 & 0.9677 \\
\hline \multicolumn{3}{|l|}{ Idiosyncratic random } & 0.179057 & 0.0323 \\
\hline & \multicolumn{2}{|c|}{ Weighted Statistics } & & \\
\hline R-squared & 0.676650 & \multicolumn{2}{|c|}{ Mean dependent var } & 0.223454 \\
\hline Adjusted R-squared & 0.662384 & \multicolumn{2}{|c|}{ S.D. dependent var } & 0.312177 \\
\hline S.E. of regression & 0.181389 & \multicolumn{2}{|c|}{ Sum squared resid } & 2.237344 \\
\hline F-statistic & 47.43278 & \multicolumn{2}{|c|}{ Durbin-Watson stat } & 0.967808 \\
\hline \multirow[t]{2}{*}{ Prob(F-statistic) } & 0.000000 & & & \\
\hline & \multicolumn{3}{|c|}{ Unweighted Statistics } & \\
\hline R-squared & 0.306068 & \multicolumn{2}{|c|}{ Mean dependent var } & 4.242176 \\
\hline Sum squared resid & 80.11656 & \multicolumn{2}{|c|}{ Durbin-Watson stat } & 0.027027 \\
\hline
\end{tabular}

Based on the results of panel data regression, the following panel data regression model equations:

$$
\log Y_{i t}=1,979+0,528 X_{1 i t}-0,024 X_{2 i t}+0,078 X_{3 i t}
$$

From the results of panel data regression with the estimation of the random effect model, it can be seen the simultaneous and partial relationships between the dependent variables and the independent variables. The results of the statistical test analysis obtained by the $\mathrm{F}$ test amount to 47,432 > from $\mathrm{F}$ Table 5,739 then Ho is rejected. This means that efficiency ports, burden customs procedures, and fixed broadband have a simultaneous effect on export performance in six ASEAN countries. In partially, based on Table 5, it is known that the calculated value for the port efficiency variable is 4,590 whose value is greater than the t-table 1,995 this means that port efficiency has a significant positive effect on export performance. On Table 5 also shows the port efficiency coefficient value of 0.528 which means that, if it is assumed that the port efficiency increases 1 unit will increase performance export in six ASEAN countries amounted to $0.528 \%$ assuming other variables were constant.

Port efficiency measured by infrastructure quality has a positive effect on export performance. This is because the export process such as loading and unloading, warehouses, port capacity, and the tools used greatly determine the speed or failure of the export process. Therefore, improvements to port infrastructure can help export performance. A similar study by Anna and Sérgio (2018) entitled "Port Efficiency and Brazilian Exports: A quantitative assessment of the impact of port procedures time". It was found that there was an increase in exported products by $1 \%$ due to a $10 \%$ reduction in ship residence time at the port. The ship's residence time at the port used as a measure in the study is a reflection of the quality of port infrastructure. The same thing was also found in Wilson et al. (2003) where there was an increase in intraAPEC trade of US \$254 billion due to the improvement of half the trade facilitation of APEC members. Half of the increase in trade facilitation comes from an increase in port efficiency.

Then for burden customs procedure variable, based on Table 5 it is known that the calculated value of ttest for the burden customs procedure is $-0,196$. This value is greater than the table value $-1,995$ this means that the burden customs procedure has no significant effect on export performance. The coefficient of the burden customs procedure variable is -0.024. This means that if the burden customs procedure variable is assumed to increase by 1 unit, it will reduce export performance in six ASEAN countries by 0.024\% as suming other variables are constant. Conceptually and in theory, the efficiency of customs procedures in this study measured by the burden customs procedure has a positive relationship with export performance. This positive relationship does not apply to this study, and also found in the Jordaan (2014) entitled "The impact of trade facilitation factors on South Africa's exports to a selection of African countries". ASEAN's efforts in triggering and implementing the ASEAN Single Window (ASW) are a form of increasing trade facilitation efficiency in terms of customs performance carried out online. This is a reform step in terms of customs, in order to improve export performance. 
The proposed customs efficiency business does not run optimally if it is not delivered properly and correctly to exporters. As it is known that the burden customs procedure variable is assessed from the perception of business people in assessing export procedures in the country concerned. Exporters' ignorance of online export procedures that seem complicated makes an assessment of the burden customs procedure worse. Even though ASEAN has provided ASW facilities that are integrated with the Single Window of each country in ASEAN. That causes a significant negative relationship between the burden customs procedure on export performance in six ASEAN countries. This is also found in the research conducted by Nuryanto (2016) entitled "Optimizing the Export Performance of MSM Furniture in Central Java through Indonesian National Single Window (INSW) Application". On Table 5 the value of t-test for fixed- broadband amount 7,335. That's a value greater than t-table amount 1,995 with probability signification 0,000 . It means fixedbroadband variable has a significant positive effect on export performance in six ASEAN countries. Therefore, fixed- broadband variable has a coefficient amount 0,078. This means if it is assumed that fixed broadband increases by $1 \%$ it will increase export performance in six ASEAN countries by $0.078 \%$ assuming other variables are constant.

Fixed- broadband with a high and stable speed of internet access is one internet network that has now been developed by many countries in the world. An increasing number of residents in a country to subscribing of fixed broadband indicates a high export opportunity for a country. Therefore fixed broadband plays an important role in improving export performance. These results are supported by Wang and Chang (2018) entitled "How Information and Communication Technology Affect International Trade: A Comparative Analysis of BRICS Countries". That research found that fixed broadband had a significant positive effect on export, where an increase of $1 \%$ with fixed- broadband can increase export by $0.220 \%$.

\section{Conclusion}

Trade facilitation is an effective way to improve export performance. Trade facilitation is also a global concern, especially for developing countries. This is evidenced by several activities such as world-level conferences that focus on trade facilitation discussions. Quoted from the World Bank and WEF, trade facilitation indicators that have an important role in improving export performance are port efficiency and burden customs procedures. In terms of technology based on the ITU and World Bank reports, the internet, especially fixed brokerage, is also a supporting factor in improving export performance.

Recognizing the important role of trade facilitation in boosting exports, ASEAN countries work hard in building quality trade facilitation. Improvement of port facilitation, the establishment of the ASEAN Single Window and the incessant improvement of the internet are proof of ASEAN's seriousness in competing internationally. In this study used panel data analysis from 2005-2016. This study aims to analysis the impact of conditions of trade facilitation in six ASEAN countries on export performance. The results of the analysis found that trade facilitation measured by port efficiency, customs procedures, and fixed-broadband had a simultaneous effect on export performance with R-squared value of 0.6766 or $67.66 \%$. Its value means that export performance is influenced by $66.77 \%$ by port efficiency, customs procedures, and fixed-broadband and the remaining $33.23 \%$ is influenced by other variables not explained in this study. Partially, port and fixedbroadband efficiency has a significant positive effect on export performance with each coefficient of 0.528 and 0.078. This means that if it is assumed that port efficiency and fixed broadband increase of 1 unit will increase export performance in six ASEAN countries by $0.528 \%$ and $0.078 \%$ assuming other variables are constant. These results are in line with the research conducted by Wilson et al. (2003) Anna and Sérgio (2018) which examined the impact of port quality on export performance. Then the positive results for fixed broadband variables found in this study are in line with the results of Wang and Chang (2018) which embodied "How Information and Communication Technology Affect International Trade: A Comparative Analysis of BRICS Countries".

However, the customs procedure shows a significant negative result on export performance with a coefficient value of -0.024 which means that if it is assumed that the customs procedure load increases by 1 unit, it will reduce $0.024 \%$ of export performance. Negative results are allegedly due to exporters' ignorance of online customs export procedures. Ignorance is caused by a lack of government socialization in this matter by customs to exporters regarding the procedures for online export. The lack of socialization makes exporters consider the procedure of online exports to be more complicated. This view makes a poor assessment of customs procedures. This was also found in the Jordaan (2014) and Nuryanto (2016).

Based on analysis and conclusions, a number of suggestions can be proposed as follows: 1) increasing efficiency of trade facilitation in this study which consists of ports of efficiency, customs procedures, and broadband still have an important role in increasing exports in six ASEAN countries. Improving port efficiency through the construction and revamping of port infrastructure has become the government's work in six ASEAN countries. Not only physical development, but the development of human resources and services contained in ports also play an important role in supporting export performance; 2) two other things that are not less important are improvements in customs, which in this study are measured by the burden of customs procedures and fixed broadband. Improvements in customs procedures, especially the simplification of the customs system that covers the number of documents, and the number of signatures need to be increased in ASEAN countries, especially those that have not implemented ASW. The existence of socialization to 
exporters by the government is certainly also a matter that needs to be taken into account. Optimizing reforms carried out by customs through online export procedures is offset by socialization to exporters, which of course will be more beneficial for exporters. In addition to socialization in the form of seminars or advertisements on social media, guiding by making video tutorials certainly helps exporters in completing online export procedures. Development of fixed broadband also needs attention, to support domestic industries in accessing international markets.

\section{References}

Adb, \& Unescap. (2013). Designing and implementing trade facilitation in Asia and the pacific. Philippines: Asian Development Bank, Mandaluyong City.

Agus, Y. P., Gusti, I., \& Wayan, S. I. (2016). Pkandangi paradiggan international: Study by empress $\uparrow \wedge$ sex with mammon in Indonesia. Journal Economy Koenitatov Turpin, 9(2), 151-158.

Anna, V. S., \& Sérgio, K. J. (2018). Port afkin \& Brazilian exports: A continental assessment won impact with port processes time. Were the World Economy, 41(9), 2528-2551.

Athukorala, P.-c. (2006). Post-crisis export performance: The Indonesian experience in regional perspective. Bulletin of Indonesian Economic Studies, 42(2), 177-211. Available at: https://doi.org/10.1080/00074910600873658.

Busse, M., Hoekstra, R., \& Koniger, J. (2012). The impact of aid for trade facilitation on the costs of trading. Kyklos, 65(2), 143- 163.

Clarke, G. R., \& Wallsten, S. J. (2006). Has the internet increased trade? Developed and developing country evidence. Economic Inquiry, 44(3), 465-484. Available at: https://doi.org/10.1093/ei/cbjo26.

Damodar, N., Gujarati, \& Dawn, C. P. (2012). Head-to-head concert. Jakarta: Salemba Empat.

Dick, H. (2008). The 2008 shipping law: Deregulation or re-regulation? Bulletin of Indonesian Economic Studies, 44(3), 383406. Available at: https://doi.org/10.1080/00074910802395336.

Grainger, A. (2008). Customs and trade facilitation: From concepts to implementation. World Customs Journal, 2(1), 17- 30.

Jordaan, A. C. (2014). The impact of trade facilitation factors on South Africa's exports to a selection of African countries. Development Southern Africa, 31(4), 591-605. Available at: https://doi.org/10.1080/0376835x.2014.907535.

Lpi. (2016). Global rankings 2016. The world bank. Retrieved from https://lpi.worldbank.org/international/global/2016.

Luthfianto, A., Priyarsono, D., \& Barreto, R. (2016). Trade facilitation and the performance of Indonesian manufacturing export. Scientific Research and Development Bulletin, 1O(1), 1-20. Available at: https://doi.org/10.30908/bilp.v10i1.29.

Martínez-Zarzoso, I., \& Laura, M.-R. (2007). The effect of trade facilitation on sectoral trade (No. 167). Discussion Papers//Ibero America Institute for Economic Research.

Maryanti, T., \& Wirianto, P. (2015). Socio-Economic Potential of the Community in the Development of Broadband Technology. Ministry of Communication and Information. 20160105190606-07-Mandiri-2-Book-Publication-B5.

Milner, C. (2008). Trade facilitation in developing countries. Retrieved from https://www.nottingham.ac.uk/credit/documents/papers/08-05.pdf.

Minges, M. (2015). Exploring the relationship between broadband and economic growth. World Development Report. No. 102955.

Nopirin. (2015). Ekonomi internasional. Yogyakarta: BPFE- Yogyakarta.

Nuryanto. (2016). Waptimlassie conja exports wicker furniture the gambling tinting malalai appalachia Indonesia national single window (Inso). Paper presented at the Science and Engineering National Seminar 2 (SENS 2).

Orliac, T. E., Moise, \& Minor, P. (2011). Trade facilitation indicators: The impact on trade costs. Oecd Trade Policy Working Papers, Oecd Publishing No. 118.

Pangestu, M., Rahardja, S., \& Ing, L. Y. (2015). Fifty years of trade policy in Indonesia: New world trade, old treatments. Bulletin of Indonesian Economic Studies, 51(2), 239-261. Available at: https://doi.org/10.1080/00074918.2015.1061915.

Perera, S., Mahinda, S., \& Stuart, M. (2017). Trade facilitation, economic development and poverty alleviation: South Asia at a glance. Poverty, Inequality and Policy. Available at: 10.5772/intechopen.69948.

Porto. (2015). The impact of trade facilitation measures on internationl trade flows. World Bank Working Paper No. 7367.

Pramana, \& Meydianawathi. (2013). Variables that affect Indonesia's non-oil and gas exports to the United States. Journal of Applied Quantitative Economics, 6(2), 98 - 105.

Qiang, C. Z.-W., Carlo, M. R., \& Kaoru, K. (2009). Economic impact of broadband. World Bank. IC4D 35-50.

Redding, S., \& Venables, A. J. (2004). Economic geography and international inequality. Journal of International Economics, 62(1), 53-82. Available at: https://doi.org/10.1016/j.jinteco.2003.07.001.

Rejekiningsih, \& Tri, W. (2012). Central Java province export concentration. Journal of Applied Quantitative Economics, 5(2), $109-118$.

Rosell, F. S. (2015). The internet and trade. Master Thesis in Economics, Departement of Economics: Lund University.

Shujie, Z., \& Zhao, S. (2009). The implication of customs modernization on export competitiveness in China, chapter 5, en U. N. (escap). Impact of Trade Facilitation on Export Competitiveness: A Regional PerspectiveUnited Nations Economic and Social Commission for Asia and the Pacific (ESCAP), 121-131.

Suparsa, \& Martini. (2016). Analysis Dia horn export commodity couponing provenance Bali. A-Journal up, 5(6), 652- 667.

Tambunan, T. (2000). International Trade and Balance of Payments. Jakarta: Library LP3S.

Taufik. (2014). Exploration of invisible day exposed on a horizontal economy. Journal Economy Koenitatov Turpin, 7(2), 90101.

Wang, M. L., \& Chang, H. C. (2018). How information and communication technology affect international trade: A comparative analysis of brics countries. Information Technology for Development. Available at: https://doi.org/10.12783/dtcse/ccnt2018/24771.

Wef. (2016). The global competitiveness report 2016-2017: World Economic Forum. Geneva. 
Widarjono, A. (2013). Economist: Introduction and Application Accompanied by Eviews Guide. YKPN STIM UPP.

Wilson, J. S., Catherine, M., \& Tsunehiro, O. (2005). Assessing the potential benefit of trade facilitation: A global perspective. The World Economy, 28(6), 841-871.

Wilson, J. S., Mann, C. L., \& Tsunehiro, O. (2003). Trade facilitation and economic development: Measuring the impact. World Bank: Policy Research Working Paper No. 2988.

World Bank. (2018). The world bank annual report 2018 (English). Washington, D.C.: World Bank Group.

World Bank Group. (2016). World development report 2016: Digital dividends: World Bank Publications.

WTO. (2018). Trade facilitation. Retrieved from https://www.wto.org/english/tratop_e/tradfa_e/tradfa_e.htm. [Accessed 21 Desember 2018].

Yadav, N. (2014). Impact of trade facilitation on parts and components trade. The International Trade Journal, 28(4), 287310. Available at: https://doi.org/10.1080/08853908.2014.922040.

Yustika, A. E. (2012). Institutional economics paradigms, theories, and policies. Jakarta: Erlangga. 